\title{
All times contemporaneous
}

\author{
Sean Reynolds a and David Hadbawnik \\ ${ }^{a}$ Department of Liberal Arts, School of the Art Institute of Chicago, Chicago, IL. \\ bepartment of English, State University of New York, Buffalo, NY.
}

postmedieval: a journal of medieval cultural studies (2015) 6, 115-119.

doi:10.1057/pmed.2015.10

The idea for a special issue of postmedieval on the intersection between contemporary poetics and medieval literature sprang from a BABEL session at the International Congress of Medieval Studies hosted by The Medieval Institute and Western Michigan University in Kalamazoo in 2011. The session centered on adventurous engagements with medieval tropes and texts by twentieth-century poets such as Jack Spicer, Robert Duncan and Anne Sexton, among others, and (happily) featured eventual contributors to this issue, including Chris Piuma and Christopher Roman. There was a lot to look at and say during the session - among the images unveiled were excerpts from Thomas Meyer's asyet-unpublished Beowulf translation, which drew an enthusiastic response from the audience - and discussion continued, as it often does, at happy hours and in pubs long after we'd finished. The feeling that we'd only scratched the surface of this topic (that there were more poets, texts and issues to talk about) spurred us to want to keep the conversation alive in a more formal, but still adventurous, setting - and postmedieval seemed like the perfect venue for that.

But there was a problem. 'Interdisciplinary' is undoubtedly a buzzword in the Humanities, but acting on it in a meaningful way is fraught with challenges. What we found as we proceeded to call for, and in some cases solicit, pieces for this issue was a sort of double-edged bewilderment that cut between medievalist 
scholars and scholars of contemporary poetry (a bewilderment that we, at times, admittedly shared). What are the terms of engagement between the two discourses? What answers, to which questions, does each bring to bear on the other? Should they be considered separate discourses at all? Wasn't part of the point of our special issue that contemporary poetics cannot be fully understood without an active engagement with (medieval) literary history? With what kind of confidence should a medieval scholar approach contemporary poetry, and vice versa? These are difficult questions, and to their credit, our contributors managed to address them, each in their own way.

Peter Buchanan notes in his essay that it is from the happy hour and pubs, from the passing of beer and lyre, that the fleeing Caedmon first came upon English poetry and began to sing it. In the mid-twentieth century, American poets Denise Levertov and Robert Duncan identified this song as the one they too had been singing. As Buchanan describes, Levertov's 'Caedmon,' and his inspiration, is a fully creaturely one, intentionally set amongst the 'warm beasts' and his own 'body sounds' so as to underline the dependence of his moment of inspiration upon carnality and inert material. In the recognition of his bodily constitution (as the 'clumsy' 'Clodhopper'), Caedmon can at last find the song that, most importantly for Levertov, enters him into a human (not animal) community and a network of social responsibilities - a pressing issue for the politically-conscious, anti-war activist poet. Duncan, meanwhile, in his 'Go, My Songs, Even As You Came to Me' invoked Caedmon as an 'everlasting' contemporary; for when the tongue-tied Caedmon told the angel 'I cannot sing,' he instituted a lyrical first-person that Duncan himself continued to inhabit in the 1980s.

As opposed to the modernist model of revitalization - as Ezra Pound writes of his Homage to Sextus Propertius, 'My job was to bring a dead man to life' (Pound, [1919] 1971, 149) - our contributors show how the dead come up and seize our own language. Alice Ladrick, for example, takes on the anachronistic and wonderfully excessive task of translating Gertrude Stein's Tender Buttons 'backwards' into Old English. Her translations into an ancestral, even foreign, language allow, in fact, for the contemporary and avant-garde to be seen a-new allowing us to better parse out Stein's play between Romantic and Germanic vocabulary and excavate to deeper levels her use of grammatical and phonic repetition. As Ladrick points out, if we continue to concern ourselves only with 'modernizing the Anglo-Saxon' - be it through translation or cross-historical criticism - we maintain a unilateral discourse with the past that fails to let the medieval (here, the Anglo-Saxons) speak. To merely revitalize the dead is not to enter into dialogue with them.

Is it true that some (medieval) texts just weren't made for their time? Anyone who has ever been in an undergraduate classroom where Chaucer is being taught is sure to have heard the astonished remark of just how 'contemporary' he seems. Likewise Kempe or Langland: they were so 'ahead of their time.' What takes us 
down this line of thought? What is it in certain medieval texts that disallows us from attributing them to exactly the time and place in which they were written? Poet Peter O'Leary in his essay takes up just such an issue in regards to Dante's Paradiso. Approaching Dante's celestial vision in Canto 28 of Paradiso through a trinity of its neologisms - 'imparadise,' 'transhumanize,' 'intrine' - O'Leary looks towards and out from the poem's internal futurity. Dante's Cantos 'are missiles for capturing the future,' he quotes Osip Mandelstam as saying; 'They demand commentary in the futurum' (Mandelstam, [1967] 2001, 67). Fulfilling then Mandelstam's prediction that 'Dante criticism belongs to the natural sciences' (Mandelstam, [1967] 2001, 67), the light of a 'transfigured' Canto 28 emerges, a new poem in which the heavenly ranks of the angels have found their analogs in astrophysics.

Christopher Roman also addresses Dante in his essay, but through the lens of contemporary avant-garde poet Alice Notley's epic poem The Descent of Alette. In Notley's radical re-visioning of Dante's quest, her female narrator Alette confronts some of the assumptions underpinning the 'masculine' form of enlightenment pursued throughout the Divine Comedy. Undoing that linear drive to the sublime, as Roman shows, means reshuffling the nature of epistemology itself seeking new ways of knowing, ways not tied to hetero-normative (or indeed, purely human) paradigms.

Carrying across the medieval into the contemporary, the very verb 'to translate' seems to demand a tense. Our conception of the chronological gap as a linear, syntactic break between centuries indeed depends upon the Western tense structure. This is exactly what compels our attention to David Larsen's translations of the classical Arabic lexical monograph. Translation itself would seem at a loss when faced with a source text in which words stand undeclined, released of the aspects of tense. In the classical Arabic lexical monograph, as Larsen shows, we discover a playful and even 'postmodern' way of thinking about relationships among words that is lost to the Western-style dictionary.

A different kind of linguistic exploration is at stake in Caroline Bergvall's monumental poetic project Meddle English. In her 'Shorter Chaucer Tales' sequence, Bergvall mines Chaucerian tropes while mashing up Middle English and contemporary jargon and slang. As Richard Owens explores in his essay, the effect of this work - hybrid and diachronic in both plot and language - is a complex critique of Chaucer's construction as a 'father of English' as well as of the implications of this construction for gendered language, finance capitalism and questions of nationalism.

What might be called 're-imaginings' of Chaucer also concerns several of our other contributors. Louise D'Arcens writes about Pier Paolo Pasolini's film I racconti di Canterbury/The Canterbury Tales, made in 1972. Pasolini, who was a poet as well as a filmmaker and keenly interested in dialect and semiotics from a Marxist perspective, cast actors from various rural dialect areas in the United Kingdom and shot the film in English, then had it dubbed over in Italian. 
D'Arcens examines how this curious decision informs and intersects with Pasolini's theory of the 'cinema of poetry' and his understanding and use of medieval culture.

Jonathan Hsy and Candace Barrington write about what they call the 'remediated verse' of poet Patience Agbabi's Telling Tales, published in 2014. Introducing West African dialects and urban London cant into her versions of Chaucer's tales, Hsy and Barrington argue that Agbabi forces us to rethink the nature of translation, appropriation and interpretation. Through complex but conscious acts of 'inversion,' Agbabi draws attention to linguistic choices in the original and in her translation, which in turn reflect issues of class and gender in the poem.

What do we expect from translations to begin with? This is the subject of Chris Piuma's essay-poem 'The Task of the Dystranslator,' which takes on Walter Benjamin's seminal essay on translation. However useful and thought-provoking Benjamin's essay remains, Piuma argues that it also tends to reinforce the notion of the translation as a somehow lesser product, subject to the 'original' and consigned to be 'faithful' to a greater or lesser extent; Piuma makes a plea for different kinds of relationships between texts.

Further exploring a topic that spurred this collection to begin with, Dan Remein writes about mid-twentieth-century poets Jack Spicer and Robin Blaser, key figures in the 'Berkeley Renaissance' (along with Robert Duncan) and their study of Anglo-Saxon with UC Berkeley philologist Arthur Brodeur. Uncovering intriguing cross-currents in critical debates that unfolded in the 1950s and 1960s in both Anglo-Saxon studies and contemporary poetry, Remein argues that not only can medieval studies inform our study of modern poetry, but the ideas of poets like Spicer and Blaser can offer provocative insights to critical debates in Old English.

Taken together, the essays collected here provide varied responses - provocative and surprising ones - to the questions mentioned above. Like all such projects, they also raise new questions that suggest further lines of inquiry. Meanwhile, the ground continues to shift. In January 2015, Salman Rushdie, in response to the 'Charlie Hebdo' attacks in Paris, called religion a 'medieval form of unreason' (Rothkopf, 2015). In March 2015, Kazuo Ishiguro published The Buried Giant, a medievalist novel set in Anglo-Saxon Britain. That same month, the Washington Post described Ferguson, Missouri, as 'reminiscent of medieval Europe' in the way its police force extracts fines and fees from citizens (McCoy, 2015). As every medievalist knows - to our annoyance more often than our delight - the term 'medieval' continues to denote a constructed, imaginary place people visit to tap into fears, fantasies and powers. Perhaps it is unreasonable, confronting us with more and more questions and refusing to be tied down to any one form or 'structure of feeling' (Williams, [1961] 2001), let alone time period. We are grateful to our contributors for grappling with these questions and showing how creative engagements with the medieval can illuminate even as they entertain. 


\section{About the Authors}

Sean Reynolds received his $\mathrm{PhD}$ in English Literature and Poetics from SUNY Buffalo in 2014. He has published essays in Postmodern Culture, Journal of Modern Literature and Les Cahiers de Lexicologie. He also edited the journal Wild Orchids with Robbie Dewhurst. Together with David Hadbawnik, he edited Jack Spicer's selected translations of Beowulf published in Lost and Found: The CUNY Poetics Document Initiative (E-mail: hendecasyllable@gmail.com).

David Hadbawnik is a poet, translator, and medieval scholar who received his $\mathrm{PhD}$ in Medieval Literature and Poetics from SUNY Buffalo, and begins teaching at American University of Kuwait in Fall 2015. His translation of books 1-6 of the Aeneid is forthcoming from Shearsman Books in 2015. In 2012, he edited Thomas Meyer's Beowulf (punctum books), and in 2011 he co-edited (with Sean Reynolds) selections from Jack Spicer's Beowulf for CUNY's Lost and Found Document Series. He is a co-editor of eth press, which focuses on creative interactions with medieval texts (E-mail: dhadbawnik@gmail.com).

\section{References}

Ishiguro, K. 2015. The Buried Giant. New York: Knopf.

Mandelstam, O. 2001. Conversations about Dante. In The Poet's Dante: Twentieth Century Responses, trans. J. G. Harris and C. Link, eds. P. S. Hawkins and R. Jacoff, 40-93. New York: Farrar Straus Giroux.

McCoy, T. 2015. Ferguson shows how a police force can turn into a plundering 'collection agency'. The Washington Post.com, http://www.washingtonpost.com/news/morning-mix/ $\mathrm{wp} / 2015 / 03 / 05 /$ ferguson-shows-how-a-police-force-can-turn-into-a-plundering-collectionagency/.

Pound, E. 1910 [2005]. Spirit of Romance, ed. R. Sieburth. New York: New Directions Publishing.

Pound, E. 1919 [1971]. Letter 160: To A.R. Orange. In The Selected Letters of Ezra Pound, 1907-1941, ed. D. D. Paige, 148-150. New York: New Directions Publishing.

Rothkopf, J. 2015. Religion is a 'medieval form of unreason': Salman Rushdie responds to Paris attacks. Salon.com, http://www.salon.com/2015/01/07/religion_is_a_medieval_form_of_unreason_salman_rushdie_responds_to_paris_attacks/.

Williams, R. [1961] 2001. The Long Revolution. Peterborough, Ontario: Broadview. 